Journal of

Milk Science

and Biotechnology
우유의 열처리가 우유품질과 영양가에 미치는 영향을 연재하면서

"오세종

전남대학교 동물자원학부

\section{Article Serialization: Effects of the Heat-treatment on the Nutritional Quality of Milk}

\author{
*Sejong Oh \\ Division of Animal Science, Chonnam National University, Gwangju, Korea
}

\begin{abstract}
Processing methods of heat treatment in milk has been developed to increase safety for the consumer by destroying pathogens that may be found in milk. Commercial pasteurization of milk in the market started in the late 1800s in Europe and in the early 1900s in the United States. In 1962, it became a requirement in Korea that all milk for sale should be treated by heat. Nowadays, heat treatment (pasteurization or sterilization) became mandatory for all milk products sold in all over the world. However, since 1987, there was a big debate about the heat-treatment of milk. Korea Society of Dairy Science and Technology (KSDST) complied the 10 scientific articles of milk heat-treatment into the book which titled "Effects of the heat-treatment on the nutritional quality of milk". Almost several hundred copies had been distributed at the symposium KSDST in 1989. Currently, no one was able to find these articles in anywhere including library etc. Thus, author decided to re-write that books in serials because these articles should be pass on their knowledge of milk science to the next generation of milk research.
\end{abstract}

\section{Keywords}

milk, heat treatment, book, nutritional quality

\section{서 론}

우리나라를 포함한 많은 국가에서는 법적으로 음용을 위한 우유나 유제품의 원료로 사용되는 우유는 모두 살균된 우유만을 사용하여야 한다. 따라서, 우유의 살균처리는 소비자에게 유제품이 전달되기 전 반드시 거처 야 할 공정 중임은 누구도 부인할 수 없다. 근대적 우유생산이 시작된 이래로 우유의 열처리 장치를 비롯하여 가열온도, 가열시간 등의 유효한 살균조건 역시 변화하여왔으며 효율적 열처리를 위한 여러 가지 방법들이 적용되었다. 현재까지 우유 살균에 사용되는 방법은 크게 3 가지 종류로 구분되며 각각의 방법에는 장단점이 있다. 초창기 살균 장치에서 수행하였던 조건과 비교하면 온도의 경우 다소 증가하고 가열시간은 짧아지는 살균조건으로 지속적으로 발전해 왔다. 우유의 살균 조건은 다른 식품과 마찬가지로 우유 내 존재하는 영양소 의 파괴 속도와 병원성 및 부패성 미생물의 사멸속도를 고려하여 결정된다(McKellar, 2003).

1950 년대까지 열처리 온도는 인체에 유해를 일으키는 병원성 세균을 불활성화 시키는 온도로 정해졌는데, 초기의 살균 온도는 결핵을 일으키는 Mycobacterium bovis를 사멸시키는 온도 $\left(143^{\circ} \mathrm{F}, 30\right.$ 분; $160^{\circ} \mathrm{F}, 15$ 초)를 기준으로 하였다가, 1957 년 미국에서 Q-fever를 일으키는 Coxiella burnetif를 불활성화 시키는 온 도 $\left(145^{\circ} \mathrm{F}, 30\right.$ 분; $161^{\circ} \mathrm{F}, 15$ 초)로 약간 상향조정되었다. 그 후 UHT(ultra high temperature) 공정이 개발 되면서 $135^{\circ} \mathrm{C}\left(275^{\circ} \mathrm{F}\right)$ 에서 순간(1 2초) 살균하는 방법으로 원유 중에 존재하는 병원성 세균과 미생물 포

This is an Open Access article distributed under the terms of the Creative Commons Attribution Non-Commercial License (http://creativecommons.org/licenses by-nc/3.0) which permits unrestricted non-commercial use, distribution, and reproduction in any medium, provided the original work is properly cited. 
자까지 사멸시킬수 있게 되었다. UHT 공정은 최근 ESL(extended shelf life) 우유 생산에 필수적인 열처리 방법으로 정착하여 국내 외 많은 유가공회사에서 사용하고 있다(Lewis, 2003). 현재의 우유 살균 방법은 우유에 대한 과학적 지식과 기계공학적 지식이 합쳐져 최적의 방법을 도출한 결과의 산물인 것이다.

우유의 열처리 논쟁이 전국을 휩쓸고 있었던 1989년, (사)한국유가공 기술과학회의 전신인 한국유가공연구회 소속 교수들은 "우유의 열처 리가 우유품질과 영양가에 미치는 영향" 이라는 제목의 책을 발간한다 (Fig. 1). 이 책은 1989년 서울 코엑스 회의장에서 개최된 추계 한국유 가공연구회 심포지엄에서 배포 되었고, 현재까지 일부 유가공 관련 전 문가들만이 소장하고 있었다. 이 책은 총 10 개의 장으로 구성되었으며 각 장마다 제목과 소제목이 있고 주로 해외 우수학술지에 게재된 논문 을 중심으로 우유의 가열살균이 우유 성분과 영양적 가치에 어떠한 영 향을 주는지를 심도 있게 고찰하였다. Fig. 1은 우유의 열처리가 우유 품질과 영양가에 미치는 영향의 책 표지 사진으로, 이 책은 인터넷이 없었던 시대의 출판물이어서 당시 발간된 책을 직접 보는 것 이외에는 전체 원문을 찾을 수 없다. 세월이 지나면서 유가공 업계와 학계에서 는 이 책의 존재 및 가치가 잊혀지고 있으며 당시 논문의 저자들은 전 부 정년퇴임을 하였고, 그 중 2 분의 교수님들은 애석하게도 이미 작고 를 하였다.

이 책의 발간으로 우유의 살균방법 차이에서 기인된 진짜우유/가짜우 유의 황당한 논란은 점차 사라지게 되었고, 논란의 출발이 되었던 파 스퇴르유업은 무균질 우유와 고름 우유 광고(1995년)에 집중 하다 1998년 부도가 났다(Fig. 2).

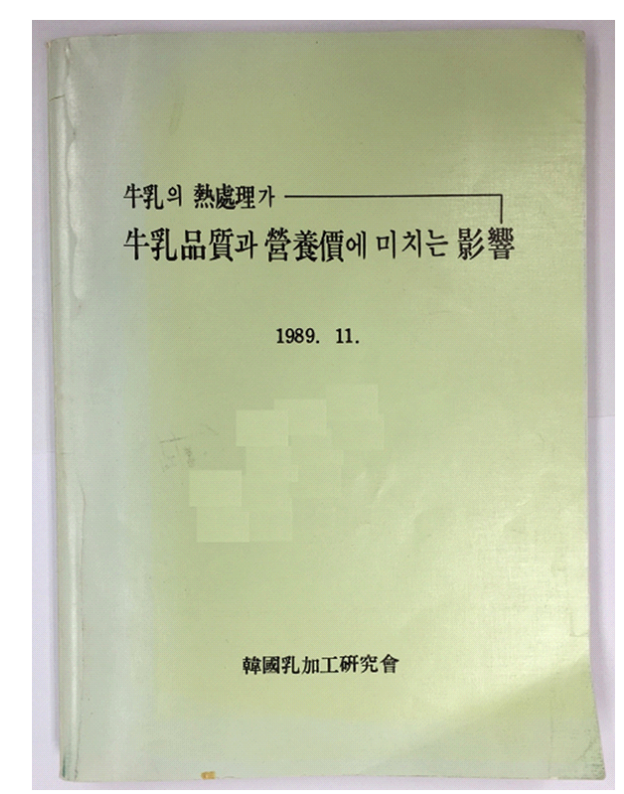

Fig. 1. The book cover of "Effects of the heat-treatment on the nutritional quality of milk"

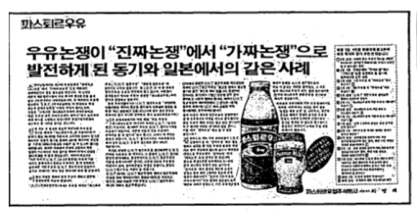

(April, 1988, Chosunilbo)

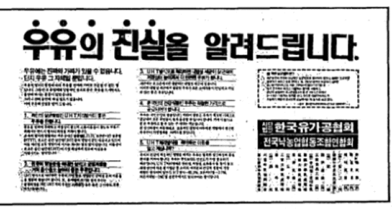

(May, 1988, Chosunilbo)
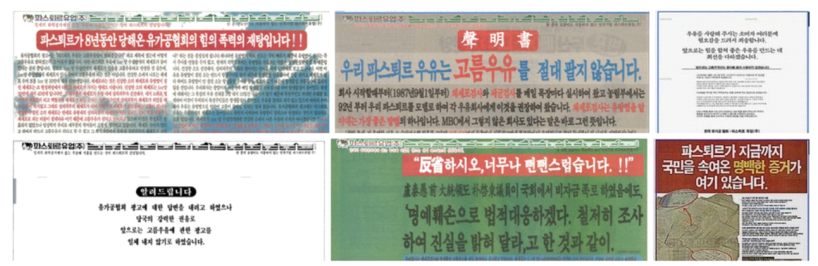

(Advertisements in daily press in 1995)

Fig. 2. The advertising pages of newspapers.

\section{본 론}

\section{1. 우유의 열처리 논쟁}

우유의 열처리에 대한 논쟁은 파스퇴르유업이라는 회사로부터 시작이 되었다고 해도 과언이 아니다. 무역업을 주로 하다가 낙농업을 새로이 시작한 최명제씨가 1987년 설립한 파스퇴르유업은 자극적인 문구와 광고로 유가공업계의 이단아로 여겨졌다. 파스퇴르유업은 사전광고 심의를 받아야 하는 방송광고보다 한결 자유스러운 신문 광고를 통하 여 자극적 문구를 사용한 마케팅 전략을 택하였고, 이를 통한 급격한 시장확장이 이루어진듯하다

Fig. 2는 1988년 당시 조선일보 1면에 광고로 게재한 파스퇴르유업의 주장과 한국유가공협회에서 게재한 광고를 보여주는 사진이다. 당시 파스퇴르 유업은 1988년부터 LTLT(low temperature long time) 열처리 공정으로 생산된 우유가 진짜우유이며 UHT 공정으로 열처리 된 우 유는 가짜우유라는 점을 지속적으로 5 대 일간지에 광고를 해오 고 있었다. 진짜우유/가짜우유라는 자극적인 단어는 소비자들에게 쉽 게 받아들여졌고, 한국유가공협회의 대응으로 사회적인 관심을 끌어 내는데 성공하였다. 노이즈 마케팅에 대한 자신감으로 파스퇴르유업 은 수 년 동안 공격적인 광고만을 게재하였다.

한국유가공연구회는 1989년 11월 우유의 열처리에 대한 과학적인 지 식을 집대성하여 “우유의 열처리가 우유품질과 영양가에 미치는 영향" 을 발간하여 각 유가공업체, 대학에 배포하였으며 이는 업체가 제기한 우유의 열처리 논란에 대하여 학계가 대응한 최초의 사례이기도 하다. 이 책에는 왜 우유에 열처리를 해야 하며, 열처리 조건에 따른 우유 성분의 변화와 그 의미에 대한 과학적 증거가 체계적으로 제시되어 있 다. 사실 파스퇴르유업의 진짜우유/가짜우유 논쟁은 일본에서 판매된 작은 책에서 기인하였는데, 그들은 $63^{\circ} \mathrm{C}, 30$ 분과 $135^{\circ} \mathrm{C}, 1 \sim 2$ 초의 열 처리 방식에서 적용된 이론적 원리를 간과했던 것 같다(McKellar, 2003). 
“우유의 열처리가 우유품질과 영양가에 미치는 영향”의 발간 이후에 우유에 대한 논란은 균질공정을 하지 않는 무균질 우유로 넘어간다. “무균질”이라는 단어는 일부 소비자들에게 깨끗한, 미생물(균)이 없다 는 의미로 오해되어 원래의 뜻과 아주 다르게 잘못 해석되었다. 파스 퇴르유업에서 생산되는 우유는 초기부터 균질공정을 하지 않았는데 그 후 남양유업이 무균질 우유를 출시하면서 다시 우유 논쟁을 유발시 킨다. 특히, 1993년 남양유업의 광고에 정치인이 등장하여 무균질 정 치인 $\mathrm{OOO}$ 이라는 신조어를 만들기까지 하였다. 참으로 우스꽝스러운 일로 우유의 지방구를 물리적으로 파쇄하여 지방이 표면으로 부상하 는 것을 억제하는 균질공정이 전혀 다른 의미로 곡해되었던 것이다. 진짜우유/가짜우유의 논쟁에서 한국유가공협회 소속 회원사인 남양유 업의 무균질 우유 광고는 많은 논란을 일으키기에 충분하였다. 이후 파스퇴르 유업은 1995 년 고름우유라는 단어를 사용한 자극적인 신문 광고를 지속적으로 하여 우유의 전체소비를 위축시키는 결과를 가져 오게 되는데, 여기에 IMP 경제 위기의 여파로 1998년 10월 최종 부 도를 맞이하게 된다. 그 후 (주)한국야쿠르트에 매각되었다가 2011년에 파스퇴르유업은 우리나라에서 영원히 사라졌으며 현재에는 일부 제품 만을 롯데푸드에서 생산하고 있다. 그러나 파스퇴르유업 사태로 인하 여 소비자들이 우유 중에 존재하는 체세포에 대하여 인식하게 되었고, 원유중의 체세포 규격이 만들어지는 계기가 되는 긍정적인 측면도 없 지 않았다. 최근 모 유업체에서 체세포 수를 가지고 자사 제품의 체세 포수가 적어서 좋다는 식의 광고를 해서 체세포 논란은 오늘날까지 지 속되고 있다. 단지 다른 점은 과거에는 체세포의 숫자가 많다는 것에 중점을 둔 반면에 최근에는 체세포수가 적은 것에 중점을 둔 것이 다 를 뿐이다. 사실 건강한 젖소에서 착유한 원유 중에는 일정수준의 체세 포수가 존재하는데 지금의 광고를 보면 우유 중에 체세포수가 검출되 지 않은 것이 좋다는 식으로 왜곡되어 받아들여 질 수 있다. 물론, 염증 에 의한 체세포수의 증가가 일어날 수 있으나 체세포수가 작다고 반드 시 청결한 원유라고 이야기하기에는 다소 무리가 따르기 때문이다. 우유를 비롯한 모든 식품은 장점과 단점을 가지고 있으므로 장점이 얼 마만큼 많고 단점이 얼마나 적은가에 관심을 가지는 것이 바람직할 듯 하다. 우리가 즐겨 먹는 두부와 콩에도 반대론자가 있으며, 이들은 한 결 같이 부정적인 측면만을 강조한다. 두부에는 estrogen과 유사한 물질인 phytoestrogen(isoflavone)이 함유되어 있는데 이것이 일종 의 환경 호르몬이라고 주장하는 것이다. 사실 phytoestrogen은 생리 적 효능이 있는 물질로 건강증진 효과에 대한 과학적 자료는 무수히 많다. 우리는 반대론자들의 주장만 믿고 두부를 먹지 말도록 해야 하 는가?

인터넷의 발달로 정보의 홍수 속에서 살고 있는 최근 우유에 대하여 조금만 검색해 보면 우유에 대한 논쟁은 쉽게 찾아 볼 수 있다. 그래도 다행스러운 것은 과학적 자료 역시 인터넷으로 쉽게 찾을 수 있다는 점이다. 물론 일부 자료는 유료로 제공되지만, 대학이나 연구소에서는 쉽게 볼 수 있다.
사실 되돌아 보면, 진짜우유/가짜우유에 대한 논란은 과학적이지 않을 뿐만 아니라 무책임한 논란거리이었다. 본 저자는 과거 통계학 수업에 서 Simpson's paradox(심슨의 역설)에 대하여 배운 적이 있다. Simpson's paradox는 부분에 대한 분석과 전체에 대한 분석결과가 상이한 현상을 말하는 것으로 막연한 자료를 이용함으로써 우리가 쉽 게 빠질 수 있는 통계적 오류의 하나이다. 진짜우유/가짜우유의 논쟁 에서 주장한 칼슘의 이용성, 유청단백질의 변성 문제는 어느 정도 인 정되는 측면도 있지만 UHT 우유는 죽은 칼슘(광고에서 주장)이고 lysine의 유효성이 감소한다는 주장은 맞지 않다(실제 lysine의 이용 성은 가열강도가 높아지면 감소함).

예를 들어 최근 30년 동안 UHT 우유 소비가 늘었고 교통사고 사망자 또한 증가하였다. 두 현상만 가지고 분석한다면 아주 높은 상관성이 있을 것이다. 이렇게 오류가 있는 분석결과로 UHT 우유 소비가 교통 사고 사망자를 늘린 원인이라고 주장한다면 여러분은 어떻게 받아들 이시겠는가?

\section{2. 유유의 열처리가 우유품질과 영양가에 미치는 영향 도서 발간}

“우유의 열처리가 우유품질과 영양가에 미치는 영향”의 도서 발간은 고려대학교 농과대학에 재직하셨던 고 김영교 교수께서 맡으셨는데, 당시 유가공 분야의 권위 있는 연구자들을 집필진으로 구성하였다. 책 의 서문은 책의 집필을 총괄하였던 고 김영교 교수께서 국한문 혼용으 로 작성하였는데, 당시의 유가공 시장 상황을 이해할 수 있다. 책의 서문은 다음과 같다.

"낙농진흥법이 우리나라에서 처음으로 제정되어 낙농산업이 육성되기 시작한지 근 30년이 되었다. 그간 낙농산업은 양적으로나 질적으로 현저 한 발전을 이룩하였으며 1988년도 말 현재 총 우 유생산량은 163 만M/T 을 넘어서게 되었고 평균 1 인당 연간소비량도 약 $40 \mathrm{~kg}$ 에 이르렀다. 이와 같은 결과는 낙농가와 유가공 업체의 끊임없는 노력의 성과이지 만, 한편 영양식품인 우유 유제품에 대한 국민의 인식이 높아지고 있 기 때문이라고 할 수 있다. 국민의 건강향상을 위해서 참으로 다행스 러운 일이라고 생각된다.

우유의 영양가치가 높다는 사실은 이미 선진 낙농국가들에 의해서 역 사적으로 증명되고 있지만, 과학적으로도 거의 완전식품이라는 것이 잘 알려지고 있다. 그런데 우유를 식품으로 이용하기 위해서는 위생적 인 처리가 필요하며 그 방법으로 가열살균을 실시하고 있다. 우유의 가열살균 방법에는 몇 가지 방법이 있는 최근 가열살균의 논의가 일부 에서는 일고 있으며 가열방법에 따라서는 우유, 유제품의 영양가에 현 저한 영향을 미치는 것으로 잘못 인식되는 경우도 있는 것 같다.

그래서 저자들은 이 기회에 이에 대한 학술적인 지식을 정리하고자 "우유의 가열이 우유의 지방, 단백질, 탄수화물, 무기물, 비타민 및 풍 미에 미치는 영향"에 대해서 국내외의 학술적 문헌을 모집 정리하여 발행하게 되었다. 본 자료에 의해서 우유의 가열이 우유와 유제품의 
성분에 미치는 영향에 대해서 올바르게 인식되기를 바란다.

아울러 본 연구에 참여하여 주신 서울대 김현욱교수, 한국식품연구원 차성관박사, 중앙대 윤영호교수, 방통대 안종건교수, 건국대 유제현 교수, 서울대 이연숙교수, 전남대 김영주교수, 인하대 허태련교수께 감사드린다"

“우유의 열처리가 우유품질과 영양가에 미치는 영향”의 총 목차는 Table 1에 정리된 바와 같으며 355쪽에 이르는 책이다. 제목에서 알 수 있듯이, 주로 열처리에 의한 우유 영양소 및 미생물학적 품질에 대 한 고찰로 되어 있다.

\section{결 론}

우유 소비 생산의 불균형은 과거에도 존재하였으며 지금도 마찬가지 이다. 우유에 대한 생산과 소비의 cycle이 어긋날 때마다 우유와 경쟁 하는 다수의 먹거리들이 그 빈틈을 비집고 들어왔다. 일부 세력들은 우유의 장점을 최소화 시키고 우유의 단점을 크게 확대 재생산 하여 소비자를 현혹 시켜온 것도 사실이다. 우유에 대한 불신과 우유를 혐 오하는 내용의 글들이 화장실의 낙서처럼 읽혀지고 인터넷과 SNS를 통하여 사실인 것처럼 확대 재생산되고 있다는 점에 대하여 많은 유가 공 연구자들은 분개하고 있다. 과거의 진짜우유/가짜우유(파스퇴르유 업) 광고, 무균질우유(남양유업) 광고, 고름우유(파스퇴르유업) 광고는 21세기 이전의 광고로 덮어둘 수 있지만, 최근의 체세포수 등급 광고 를 보면서 유가공 업계 간의 이전투구식의 논쟁이 증폭되어 전체 유가 공 산업의 위축을 가져오지 않을까 하는 우려가 생긴다.
과학은 단정적이기 어려우며 그 이유는 $100 \%$ 완전한 것이 아니기 때 문이다. 우유에 대한 과학적 지식도 역시 100\% 완전하지 않다. 그러 나 아주 오래전부터 음용해온 우유와 유제품의 건강증진 효과에 대한 연구자와 다수의 소비자들의 믿음은 시간이 지나도 변하지 않는다. 온고지신(溫故知新)이라 했던가? 우리는 과거에 있어왔던 유가공 역사 를 되새기면서 미래의 유가공 산업을 더욱더 발전시켜야 할 의무가 있 다. 본 저자는 Journal of Milk Science \& Biotechnology 34권 4 호부터 제 1 장인 “우유 열처리 기술의 발달사" 부터 순차적으로 원고 를 편집 게재할 계획이다. 본 논문의 학술적 가치를 인정하여 원고를 심사하여 주시고 게재를 허가해 준 학술지 편집위원회에 감사드린다.

\section{References}

1. Lewis, M. J. 2003. Improvements in the pasteurization and sterilization of milk. Pages 81-103 in Dairy processing improving quality. G. Smit ted. CRC Press, Washington, DC, USA.

2. McKellar, R. C. 2003. Modeling the effectiveness of pasteurization Pages 104-106 in Dairy processing improving quality. G. Smit ted. CRC Press, Washington, DC, USA.

Table 1. List of book chapters

\begin{tabular}{lcc}
\hline \multicolumn{1}{c}{ Chapter title } & Author (affiliation) & Page \\
\hline 우유 열처리기술의 발달사 & 김현욱(서울대학교) & $3-22$ \\
열처리에 의한 우유 미생물 사멸효과 & 차성관(한국식품연구원) \\
우유 열처리에 의한 병원균 사멸효과 & 윤영호(중앙대학교) \\
열처리가 우유효소에 미치는 영향 & 안종건(한국방송통신대학교) & $23-64$ \\
우유의 열처리가 우유단백질의 이화학적 성질과 영향에 미치는 영향 & 김영교(고려대학교) & $97-144$ \\
열처리가 탄수화물의 영양가에 미치는 영향 & 유제현(건국대학교) & $145-187$ \\
열처리가 우유칼슘과 무기질의 영양가에 미치는 영향 & 이연숙(서울대학교) \\
가열에 의한 우유 비타민의 안정성과 저장중의 변화 & 김영주(전남대학교) \\
우유 지방의 가공처리과정중의 변화 & 허태련(인하대학교) \\
우유의 열처리가 우유품질과 영양가에 미치는 영향 & 김현욱(서울대학교) & $231-279$ \\
\hline
\end{tabular}

